\section{B A Institute of \\ YK Business Administration \\ 六下 \\ Karachi \\ Leadership and Ideas for Tomorrow}

Business Review

Volume 11 Issue 2 July-December 2016

7-1-2016

\title{
Review (meta analysis) of research studies conducted on the depiction and effects of violence on silver screen in the world
}

\author{
Erum Hafeez \\ Institute of Business Management, Karachi, Pakistan
}

Follow this and additional works at: https://ir.iba.edu.pk/businessreview

Part of the Digital Humanities Commons

\section{(c) (1)}

This work is licensed under a Creative Commons Attribution 4.0 International License.

\section{Recommended Citation}

Hafeez, E. (2016). Review (meta analysis) of research studies conducted on the depiction and effects of violence on silver screen in the world. Business Review, 11(2), 85-92. Retrieved from https://doi.org/ 10.54784/1990-6587.1071

This article is brought to you by iRepository for open access under the Creative Commons Attribution 4.0 License and is available at https://ir.iba.edu.pk/businessreview/vol11/iss2/8. For more information, please contact irepository@iba.edu.pk. 


\title{
DISCUSSION
}

\section{Review (Meta-Analysis) of Research Studies Conducted on the Depiction and Effects of Violence on Silver Screen in the World}

\author{
Erum Hafeez \\ Institute of Business Management, Karachi, Pakistan
}

\begin{abstract}
This article reviews the literature on the depiction and effects of violence in motion pictures. It provides an overview of studies in chronological order starting in the 1920s and covers motion pictures from America, Britain, India and Pakistan.
\end{abstract}

Key Words: Motion Pictures, Filmology, mass audience, perception of reality, Bollywood, onscreen violence, real-life crimes

\section{Introduction}

Since its commencement in the nineteen century, Motion Pictures have been preferred as a shared source of recreation that attracts and influences each one of us at some stage of our life. There were some pioneer researchers such as Jarvie (1970) who claimed that "Hollywood motion pictures projected a world view as well as sociological implications for the roles in films which were representative of societal views but not that of reality."'Tudor (1974) on the other hand identified contrasting orientations toward theories of film 'models' and 'aesthetics'. The former are aimed principally at scientific comprehension of (how) film (operates as a medium), while the latter are "aimed at principally making evaluative judgments."

\section{Review of the Studies}

Many scholars seem to be preoccupied with various aspects of individuals' behavior pattern and its possible correlation to the movies of its times than the films themselves. It was an approach Metz (1974) labeled 'filmology'. Films are often examined to explore if they simply depict reality as it is or they create the reality of its era. "The question of whether or not the mass media are capable of moulding the minds of the audience is an extremely complex one, and the answer is subject to a wide variety of factors. 'Some people are influenced by some media at some time' is a commonly held belief by social scientists; but exactly how this influence takes place is open to speculation (Garth Jowett 1989)."

Feature films which are solely produced for commercial purposes of churning profit often rely on popular subjects, stereotype characters and predictable climax to attract mass audience whose presence in cinema halls determines the success and failure of any movie irrespective of its artistic value. It is therefore understandable that most motion pictures depict popular reality and adhere to safe and tried formula approach for wider acceptance and instant success.

There are no two views that films have been a powerful entertainment medium for more than 90 years since its inception. So, whether they are reflecting or shaping, they are contributing to our overall social perspective. Above all movies play a significant role to the collective vision of things which most of us never come across in our immediate experiences. 
Films create a new form of collectivism known as the 'mass public' by transforming selected private perspectives into broad public perspective as identified by George (Gerbner 1967).

The powerful role of movies as a source of 'image formation' was a special area of researchers' interest in the last century, and many studies were conducted to examine movies impact on the collective public consciousness alongside its crucial influence on the psychological development of individual viewers (Baldwin 1976; Deming1969; Rosenbaum 1980).

On the other hand, contemporary movie scholars seem to be more interested to discover a connection between the silver screen images and the socio-cultural conflicts of the relevant era (Biskind 1983; Polan1986; Sayre 1982). Biskind (1983) comments "Movies influence manners, attitudes and behavior. In the fifties, they told us how to dress for a rumble or a board meeting, how far to go on the first date, what to think about Martians, or Jews, blacks and homosexuals. They taught girls whether they should have husbands or careers, boys whether to pursue career or pleasure; they told us what was right and what was wrong, what was good and what was bad; they defined our problems and suggested solutions (Garth Jowett 1989)."

Primitive studies about the influence of movies were predominated by the 'mass society paradigm' and their results were markedly different from the later researches which were representative of the 'limited effects paradigm'. In the thirties, researchers condemned movies for creating serious and lasting impact on youth and adolescents through onscreen violence. However, till seventies, the fears against the screen monsters tamed down with the findings that the nastiest effects of fictionalized violence would likely to limit to a minority of teenage boys from disturbed families who were naturally inclined to deviance (Baran 2001).

The anti and pro-social effects of television and motion pictures are intensely researched in all areas of mass media studies for decades. Heated debates are conducted in Universities and Colleges that focus on the repercussions of anti-social and pro social visual content. Such vehement concern is dated back to the 1920s when critics blamed motion pictures with charge of persuading kids under harmful influence of Mass media.

"The Motion Picture Research Council with the support of Payne fund, a private philanthropic organ, sponsored the voluminous 13 studies (1929-1933) on the movies' influence on children which concluded that movies were potent source of information, attitudes and behavior for children and most of these learning had antisocial overtones" Wimmer and Dominick (2005). The study titled "Motion Picture \& Youth" was an attempt to provide a quantitative analysis on moral behaviors that inadvertently analyze the behavior's relation with excessive motion picture viewing by children including their sleeping patterns, social conduct, racial perceptions, standard of morality, criminal and sexual delinquency in males and females. "For example, one of the studies determined that 28 million minors $(37 \%$ of total audience) attended the movies weekly and that 11 million of these were children under the age of 14 (17\% of total audiences)."

Besides, researchers determined that movies elicited morally unacceptable behaviors like drinking, gambling, adultery, divorce and criminality. It was further identified that the three leading topics of commercial movies in 30s included love $(29.6 \%)$, crime $(27.4 \%)$ and sex $(15 \%)$, making a sum total of 72 percent of all movie themes. Moreover, evidence suggests that such movies also encouraged petty theft and inappropriate sexual conduct among adolescents. Overall Payne Fund Studies came up with the results which were not fatal enough to be enacted into legislation against the motion picture industry. There was not 
enough evidence to prove that motion picture viewing has such a dire impact on the well rounded upbringing of children. (Pattison 2006)“

Herbert Blumer (1900) and Philip M. Hauser (1909), both professors of Sociology at the University of Chicago studied the link between movie viewing and eccentric, delinquent behaviors in youth. The material secured in the investigation (through interview transcripts of delinquent criminals \& non-delinquent boys and girls) show that motion pictures may contribute either directly or indirectly to delinquency and crimes. There are two major factors that determine the nature and direction of motion pictures' impact; firstly, the variety and scope of themes portrayed on screen, secondly, social milieu, attitudes and interests of observer. The effect is neutral on various segments of society. Youngsters from high-end delinquency segments are sensitized by the happenings around them and those in the low rate delinquency vicinity are immune to such criminal behaviors impelled by the screen."(Movies, Delinquency \& Crime; Payne Fund Studies 1933).

In 1960, Joseph Klapper summarized the social impact of mass communication known as the minimal effect position in which he concluded that media most often reinforced individual's existing attitudes and predispositions. His viewpoint was influential in the development of theory of media effects which downplayed potential harmful media effects. (Wimmer and Dominick 2005).

Despite Klappar's minimal effect theory, opinion leaders and common men persistently criticized films for nuisance in society, which apparently seem to become increasingly and graphically violent. Thus "Wes Shipley and Gray Cavender of Arizona State University analyzed the leading five box-office hits with highest profit rate in one year period in the last four decades including.1964, 1974, 1984 and 1994.Their analysis describes the trend of mutiny. It is based on careful coding of films and focuses on individual violent acts, graphic violence and death. They found that these two variables increased throughout the period studied though not exactly in a linear proportion and is mostly restricted to particular film genres (Shipley W 2001).”

On the other hand, Jessica Allen conducted a longitudinal content analysis of films from 1945-91 to identify the 'Changing Generic Location of Crime in Films'. The key hypotheses were, "Is the number of films containing crimes increasing?" If yes; which type of movies? Referring to the synopses of all movies showcased in Britain between 1945 and 1991, the researcher recognized changes in main films genres and their percentage of crime contents. However, it was found that "the overall proportion of crime films and the proportion of crime content in all films genres have remained constant. No difference was found between British and US films in terms of proportion of crime content by genre.

This historical content analysis provides an overview of trends in the inclusion of crime in film. (Allen, Livingstone and Reiner Autumn 1997)."

Later, Theresa Webb from University of California conducted a study by the title 'PG-13 rated Films adversely-exposed-kids to violence'. She testified all the PG-13 rated films from the list of 100 top-grossing movies of 1999 \& 2000 identified by a Hollywood reporter. Every single scene of violence was coded by her team with reference to its content and context in order to evaluate how it was projected on screen; favorably or unfavorably. The study shows that violence pervaded around 90 percent of the movies sampled. Moreover, the media depiction of violence contributes to the teaching of violence, leading to amplified anger, concern for individual' safety and desensitization to the pain (Webb 2009). 
In Indo-Pak subcontinent, very few researches on Indian movies, and a number of research-based newspapers and magazine articles are found that are highlighting the historical evolution of Indian film industry to the current status. Akbar. S. Ahmed's research paper titled as Bombay Films; the Cinema as Metaphor for Indian Society and Politics printed in the Modern Asian Studies in 1992 narrates, "It is difficult to distinguish between art and life in (Indian) society. They no longer imitate each other but appear to have merged. Political philosophies, social values, group behavior, speech and dress in society are reflected in the cinema and, like a true mirror, reflect back in society. The understanding will help us to observe how Indians perceive themselves and how current Indian films mirror India's role and perception of itself as a big brother or regional power in South Asia and what impact this has on neighboring countries like Pakistan, in particular their cinema \&society. (Ahmed 1992)."

Parmesh Shahani in his article Media in Transition, printed in December 2005, wrote that the term Bollywood is primarily coined in the eighties by a journalist from Indian film magazine 'CineBlitz". It represents the Bombay-based Hindi film industry recognized as the biggest annual producer of feature films (Shahani 2005)."

Sashi Baliga, Editor Filmfare commented on Nov 19, 2004 that Bollywood films are viewed worldwide including regions such as South Asia, South East Asia, East Africa, Mauritius, the Caribbean, The Middle East Britain, Canada, Australia, US\& Russia (Personal Correspondence with ShashiBaliga: Editor Film fare Magazine 2004).

Business Week magazine figures printed on Dec 22002 indicates that "around 3.6 billion tickets were sold globally in 2001 for Bollywood films vs. 2.6 billion for Hollywood films making it the most popular art form in the world. (Shahani 2005)"

Srividya Ram Subramanian and Mary Beth Oliver conducted an exploratory content analysis to observe portrayals of sexual violence in popular Hindi films in 2000. Nine films were arbitrarily chosen from box office hits between 1997-99. It was found that women were mostly portrayed as victims than men. Heroes were more likely to be involved in moderate violence such as sexual harassment especially targeting the female lead that ultimately leads to infatuation and then filmy romance. While intense sexual violence was condemned as criminal and serious, moderate sexual violence was often glamorized as fun and adoring in Indian films (Ramasubramanian and Oliver 2003).”

Kiran Shaheen (1999) studied Portrayal of Police Torture in Hindi Films and Television Serials and its impact on Children in India. The study was planned to understand how torture and other forms of violence replicated in popular electronic media and how the media consequently manipulate viewers particularly children. "It involved an analytical review of violence depicted in films and TV serials of 1970s, 80s and 90s. According to the results, around 178 acts of violence were counted in one form or the other in a single day televised programs across the channel offered in India which is often blatant and brutal in its treatment.

The study revealed that the children from poor class spent more time watching television than the kids from upper and middle classes. Moreover, the children from poor class seemed to be more afraid of such torture scenes since they often exposed to such situations in their day-to-day lives. Boys especially from lower income group were found to be fonder of police torture and police characters than their female counterparts. While it's rather middle and upper income group kids who drew pleasure from the scenes where police torture the villain may be because of their protected position in the society. (Shaheen 1999) 


\section{Discussion and Analysis}

The in-depth analysis of the literature review of the topic discloses that antisocial effects of Motion Pictures is one of the most heavily researched area in all Mass Media studies. Concerns about the problem were aroused in 1920s. However, earliest research found on the topic was the multi-volume Payne Fund Studies that were conducted from 1928-33 with focus on Movies Influence on Children. It identified movies as a powerful source of information, attitudes and behavior for children but also established that most of this learning had harmful implications. The series of 13 studies conducted under the Motion Picture Research Council was a milestone in the field of research that tried to correlate diverse immoral behavior patterns with excessive movie viewing. Payne Fund Studies provided foundation for the future research by quantifying hypothesis about movie attendance and themes in 1930s.It found that 72 percent of commercial films in 1930s revolved around love, crime and sex which remain the same even today as evident from the present study that content analyzed movies across four decades. However, these studies were unable to establish evident link between movie viewing and major crimes except some petty thefts and inappropriate sexual conduct in criminally inclined children.

Other researchers such as Blumer 1900-87 and Hauser (1909) were able to conclude that motion pictures may incite delinquency and even crime considering variety of projected themes as well as social background and personal leaning of the viewers. The same violent movie may provoke a child in the high rate delinquency area while it desensitizes other to violence from low rate delinquency area.

On the contrary Klapper 1960 simply downplayed potential harmful effects of media by maintaining that media only reinforces individual's established approach and inclination, hardly foster anything new. Despite the fact that early researchers were unable to prove any direct relation between real and reel world violence, public and politicians continued blaming movies for increasing social and moral crimes which were publicly assumed to become increasingly violent with the passage of time.

From various aspects, three studies Shipley and Cavendar (1964-94), Allen (1945-91) and Web (1999-2000) content analyzed top grossing box office hits to code and calculate the intensity and rate of violence in US and Britain respectively. Shipley and Cavendar found that graphic violence and death increased across the four decades but in a non-linear manner. Violence was limited to a particular genre as found by Allen's longitudinal content analysis that covered films from 1945 to 1991 . The study discovered that overall proportion of crime films and that of crime content in all film genres have remained same during fifty years.

Moreover, similar characteristics are seen both in US and Britain in terms of proportion of crime content by genre. On the contrary, Webb's recent study on the carefully sampled PG -13 rated films from the 100 top grossing movies of 1999 and 2000 maintained that violence pervaded 90 percent of the films and it contributed to teach violence techniques, increasing aggression, anxiety and indifference towards real-life miseries in excessive viewers.

Overall, a critical review of the research studies conducted on the topic in US and Britain indicates that the widespread perception regarding the antisocial effects of motion pictures was never proved directly as several studies found indirect relation between excessive movie viewing and criminal tendencies in favorable socio-economic and personal scenarios. 
Unfortunately, in Indo-Pak sub-continent, very few researches were conducted to evaluate the effects of strikingly popular Indian film industry. One exclusive research paper on the topic (Akbar Ahmed, 1992, appeared in Cambridge Journals, Online Modern Studies) declared Indian Cinema a Metaphor of Indian society and politics. He remarks that the two no longer imitate each other but seem to have merged so much so that it affects India's selfperception and its role as a regional power in South Asia, which evidently have direct and powerful impact on the cinema and society of its neighboring countries such as Pakistan.

In the absence of relevant research studies, a few authentic publications such as Filmfare and Newsweek were quoted to assert the fact that Bollywood is the world's largest film industry. Bollywood films are popular across the globe and even beat Hollywood in international market with a difference of one billion in 2001 (Business Week issue). In the wake of such fame, it is not irrelevant to understand the magnitude of the impact of the most watched art form in the region.

There were two relevant researches using exploratory content analysis to examine portrayal of sexual violence (Ram Subramanian and Beth2000) in popular Hindi films and portrayal of police torture (Shaheen 1999) in Hindi films and TV serials respectively. The former research randomly studied late 90 s box office hits concluded that victims of onscreen sexual violence were mostly women. Though serious sexual violence was often portrayed as criminal; moderate violence perpetrated by heroes such as sexual harassment was often depicted as a likeable act. Iran's study analyzed films and TV serials from 70s, 80s and 90s in a day across the channels and found a large number of violent acts which were often portrayed graphically.

In absence of any research in Pakistan on the topic, a study "Portrayal of Violence in Indian Movies and its effects on violence in Real-life Crimes in Pakistan" was conducted by the writer in 2006. The study followed Shipley and Cavender's research for sampling and covered popular Bollywood hits from 1970s to 2000s. Like most of the researches reviewed in literature, it could not find any direct, causal link between violence in Indian films and violence in society. However, there seems to be a delayed, indirect connection as it's noticed that rate of violence in Pakistani society fluctuates and follows trends and frequency of violence in films in previous decades. The impact of media messages on society is rather slow and gradual.

\section{References}

Ahmed, Akbar S. (1992), Bombay Films: The Cinema as Metaphor for Indian Society and Politics. Modern Asian Studies, 26(2), 289-320.

Aidman, A. (1997). Television Violence; Content, Context, and Consequences. Eric Digest.com.

Allen, J., S Livingstone, and R Reiner. (1997). The Changing Generic Location of Crime in Films : A Content Analysis of Film Synopses, 1945-1991. Journal of Communication, 47(4), 89-101.

Baran, Stanley J. (2001). Introduction to Mass Communication; Media Literacy and Culture. Mayfield Publisher.

Biskind, Peter. (1983). Seeing is believing; How Hollywood taught us to stop worrying \& love the fifties . Newyork.

Chris Broodryle, Willien. (2006). The movie image; contemporary film analysis and analytical psychology. University of Pretoria.

90 
Coyne, Sarah M. (2007). Does Media Violence Cause Violent Crime. Springer Science + Business Media B.V., 16, 206-2011.

Department of Health and Human Services. (2001). A Report of the Surgeon General: Youth Violence. gov/library/youthviolence/chapter 4/appendix4b.html.

Douglas, J, and M Olshaker. (1999). The Anatomy of Motive. 82-87. New York: Scribner.

Federal Trade Commission. Marketing Violent Entertainment to Children, A review of SelfRegulation and Independent Practices in Motion Pictures. Washington D.C.: Federal Trade Commission, Sept. 2000 printed in July 2001.

FEPP.FactSheets ; Media 2004. http://www.fepproject.org/factsheets/mediaviolence.html (accessed Jan 2004).

Fowles, J. Jib Fowles \& Others; the Case for TV Violence. Sage Publications, 1999.

Freedman, J. "Media Violence \& its Effects on Aggression; Assessing the Scientific Evidence." University of Toronto, University of Toronto, 2008.

Garth Jowett, James M. Linton. Movies as Mass Communication; Sociology of the movies. Second. Newbury Park: The SAGE COMMTEXT Seies, 1989.

Gosselin, A, and J DeGuise. "Violence on Canadian Television \& some of its Cognitive Effects." Canadian Journal of Communication 22, no. 2 (1997).

Hauser. "Movies, Delinquency \& Crime.” Nekyork: Arno Press, 1970.

Hauser, Herbert Blumer \& Philip M. "Movies, Delinquency \& Crime; Early Approaches.” 114, Chapter 1 . 9(1)2001.

Heins, M, and C Cho. "Media Literacy:An Alternative to Censorship." Free Expression Policy Project. 2003.

Henslin, James M. Sociology_A Down to Earth Approach. Edited by Third. United States of America: Allyn and Bacon, 1997.

Jarvie, I.C. Movies and Society. NewYork : N.Y.: Basic Books, Inc.Lewis,D. (1940), 1970.

Kerbo, Harold R. Sociology; Social Structure \& Social Conflict. California Polytechnic State University: National Book Foundation, Islamabad.

Khan, Rahim,F, and I Rashid. "Violence in the Dramatized Entertainment of PTV." Research Journal Gomal University (B)13, no. 2 (1993): 205-222.

Kunczik, M. Recent Research on Media \& Violence; Media Violence \& Challenges facing Modern Societies. UNESCO, Asia Pacific Institute for Broadcasting Development; UNESCO, April 2003.

“Movies, Delinquency \& Crime; Payne Fund Studies." In Influence of Motion PIctures upon Children \& Youth. Macmillan, 1933.

"National TV Violence Study, 1996-1997." Mediaawareness.ca . www.mediaawareness.ca/eng/resources/research_documents/rep/violence.

Nicholas, Vardac A. Stage to Screen ; Theatrical origins of early film. NewYork: Da Capo Press, 1949. 
Pattison, L. "Taking the Movies to School: Science, Efficiency, and the Motion Picture Project, 1929-1939." History of Intellectual Culture 6, no. 1 (2006).

Personal Correspondence with ShashiBaliga: Editor Film fare Magazine. 10 November 2004. http://pipl.com/directory/name/Baliga/Shashi (accessed 2010).

Polan, Dana. Power and Paranoia; History, Narrative, and the Smerican Cinema, 1940-50. NewYork: Columbia University Press, 1986.

Prince, Stephen. "Link between media \& crime; screening violence." Safer media for a safer society. mediamarch.org.uk/howisthemedialinkedwithc.htm (accessed 6 7, 2011).

Ramasubramanian, S, and Mary B Oliver. "Portrayal of Sexual Violence in Popular Hindi Films:1997-1999.” Sex Roles (Index Roles/ Springer Science+ Business Media, B.V. Karachi) 48, no. 7-8 (2003): 327-336.

Rao, Shakuntala. "The Globalization of Bollywood; An enthbography of non-elite audiences in India." The Communication Review (Taylor and Francis Group, I.I.C.), 2007: 57-76.

Sayre, Nora. Running Time: Films of the Cold War. NewYork, 1982.

Shahani, P. "Bollyspeak; Media in Transition; MS 801; Final Assignment." google.com. Dec 2005. http://parmesh.net/Bollyspeak.pdf (accessed 2010).

Shaheen, K. "Portrayal of Police Torture in Hindi Films \& Television Serials and its impact on Children." CEHAT- Centre for Enquiry Into Health and Allied Themes. 1999. www.cehat.org/publications/rd09r13.html.

Shipley W, Cavender G. "Murder \& Mayhem at the Movies." Journal of Criminal Justice and Popular Culture; Arizon State University (Arizona State University) 9, no. 1 (2001): 114.

Signorielli, N. "History Of Violence in the Media (TV); Contemporary World Issues." In Violence in the Media-Contemporary World Issues Series. ABC-CLIO, Incorporated, 2005.

Stossel, S. The Man who counts the Killings. May 1997. www.theatlantic.com/issues/97may/gerbner.htm.

Thompson, William E., and Joseph V. Hickey. Society in Focus; Introduction to Sociology. Edited by Third. Longman. An imprint of Addison Wesley Longman, Inc., 1999.

Tudor, Andrew. Teories of Film. NewYork: Viking Press, 1974.

Vivian, J, Allyn, and Bacon. Media of Mass Communication. 9th. Edited by Allyn and Bacon. 2009.

Webb, T. "PG-13 rated Films Adversely Exposed Kids to Violence." biomedicine.org, University of California, Los Angeles. 3007 2009. http://www.biomedicine.org/ (accessed 2010).

Wimmer, Roger D, and Joseph R Dominick. "Research in Media Effects." In Mass Media Research-An Introduction, by Roger D Wimmer and Joseph R Dominick, 393-396, chapter VII. Wadsworth Publishing, 2005.

Zuberi, Nisar A. "Effects of TV on Children of Middle Class Families in Karachi." 1992. http://prr.hec.gov.pk/Thesis/274 OR http://eprints.hec.gov.pk/624/ . 